\title{
Efektivitas Aplikasi Islami Terhadap Muslim Generasi Z dalam Meningkatkan Kemampuan Membaca Al-Qur'an
}

\author{
Ari Hartawan \\ Teknik Mekatronika, Departemen Teknik Mekanika dan Energi, Politeknik Elektronika \\ Negeri Surabaya \\ Email: ari.hartawan962@gmail.com \\ Imamul Arifin \\ Teknik Mekatronika, Departemen Teknik Mekanika dan Energi, Politeknik Elektronika \\ Negeri Surabaya \\ Email: imamul@pens.ac.id \\ Yogi Dwi Prasetyo \\ Teknik Mekatronika, Departemen Teknik Mekanika dan Energi, Politeknik Elektronika \\ Negeri Surabaya \\ Email: pyogidwi@gmail.com
}

Naskah diterima: 24 November 2021, direvisi: 10 Januari 2022, disetujui: 12 Januari 2022

\begin{abstract}
As a generation that lives in the era of technological development, Generation $\mathrm{Z}$ sees smartphones no longer as devices but more as a lifestyle. The rapid growth of technology makes the smartphones that they hold offer many innovations that can facilitate all aspects of their lives, including worship by reading the Al-Qur'an through Islamic applications. It is believed that an Islamic application with various features and flexibility can improve the user's Al-Qur'an reading ability, especially the technology-savvy Generation Z. By involving 85 Muslim respondents of generation $Z$ through an online survey, this study seeks to find out how practical Islamic applications are to increase the skills of reading the AlQur'an for generation Z Muslims. Various opinions of respondents are presented and then categorized so that these opinions result from a percentage stating that Islamic applications are declared quite effective to improve Gen Z's skills in reading the Al-Qur'an.
\end{abstract}

Keywords: Generation Z, Islamic Apps, Al-Qur'an.

\begin{abstract}
Abstrak
Sebagai generasi yang hidup di era perkembangan teknologi, Generasi Z melihat smartphone tidak lagi sebagai perangkat tetapi lebih sebagai gaya hidup. Pesatnya perkembangan teknologi membuat smartphone yang mereka pegang menawarkan banyak inovasi yang dapat mempermudah segala aspek kehidupan mereka, termasuk untuk beribadah dengan membaca Al-Qur'an melalui aplikasi islami. Aplikasi islami yang menyediakan berbagai fitur dan fleksibilitas diyakini dapat meningkatkan kemampuan penggunanya untuk melafazkan ayat-ayat Allah SWT tersebut, terlebih Generasi $Z$ yang paham teknologi. Dengan melibatkan 85 responden muslim generasi $\mathrm{Z}$ melalui survei online, penelitian ini berupaya untuk mengetahui seberapa efektif aplikasi islami untuk menambah keterampilan muslim generasi Z membaca Al-Qur'an. Berbagai pendapat responden disajikan kemudian dikategorikan sehingga dari pendapat tersebut menghasilkan persentase yang menyatakan bahwa aplikasi islami dinyatakan cukup memberikan dampak kepada generasi $\mathrm{Z}$ untuk menambah kemampuan membaca Kitabullah tersebut.
\end{abstract}

Kata Kunci: Generasi Z, Aplikasi Islami, Al-Qur'an 


\section{A. Pendahuluan}

Generasi $\mathrm{Z}$ atau disebut sebagai Gen $\mathrm{Z}$ merupakan generasi yang terlahir diantara tahun 1997 sampai dengan tahun 2012. Generasi pascamilenial ini menempati 27,94\% dari total komposisi penduduk di Indoensia ${ }^{1}$. Mereka terlahir, hidup, dan beraktifitas di zaman serba teknologi sebagaimana yang terjadi pada masa ini. Mereka cenderung melakukan segalanya dengan teknologi, bahkan kemampuan generasi ini dalam menggunakan teknologi sama alaminya layaknya mereka benafas ${ }^{2}$.

Sebagai generasi yang berinteraksi langsung dengan teknologi, smartphone tidak lagi dilihat sebagai perangkat tetapi lebih ke cara hidup ${ }^{3}$. Smartphone yang mereka genggam setiap hari menghadirkan banyak inovasi yang dapat memudahkan segala aspek kehidupan, termasuk untuk beribadah kepada Allah SWT melalui aplikasi islami yang terpasang di dalamnya. Aplikasi Islami menyediakan banyak fitur yang dapat digunakan pengguna untuk mendukung aktivitasnya dalam beribadah kepada Allah SWT. Misalnya adalah ibadah dengan melafazkan ayat-ayat Al-Qur'an. Ditengah kesibukan duniawi, padatnya aktivitas, kapanpun, dan dimanapun penggunanya dapat tetap berinteraksi dengan Al-Qur'an. Aplikasi Muslim Pro menyampaikan sebagian besar orang lebih memilih online atau menggunakan aplikasi seluler untuk membaca Al-Quran hingga Alkitab atau sumber daya religius lainnya daripada menggunakan cetakan tradisional ${ }^{4}$.

Muhammad Ali al-Shabuni menyebutkan bahwa Al-Qur'an adalah Kalam Allah yang tiada tandingannya, diturunkan kepada Nabi Muhammad Saw. penutup para Nabi dan Rasul, dengan perantaraan malaikat Jibril a.s dan ditulis pada mushaf-mushaf yang kemudian disampaikan kepada kita secara mutawatir, serta membaca dan mempelajarinya merupakan suatu ibadah, yang dimulai dengan surat al-Fatihah dan ditutup dengan surat an$\mathrm{Nas}^{5}$. Al-Qur'an sendiri telah menganjurkan supaya kita membacanya, sebagaimana firman Allah SWT dalam QS Al-`Alaq [96]:1-5.

${ }^{1}$ Badan Pusat Statistik, Hasil Sensus Penduduk 2020 Berita Resmi Statistik No. 7/01/Th. XXIV, 21 Januari 2021, n.d.

2 Ranny Rastati, "MEDIA LITERASI BAGI DIGITAL NATIVES: PERSPEKTIF GENERASI Z DI JAKARTA," Jurnal Kwangsan 6, no. 1 (June 29, 2018): 60.

3 "KEPEMIMPINAN MASA KINI - Google Books," accessed November 27, 2021, https://www.google.co.id/books/edition/KEPEMIMPINAN_MASA_KINI/rosaEAAAQBAJ?hl=id\&gbpv= $1 \&$ printsec=frontcover.

4 "Muslim Pro: Kini Orang Lebih Suka Baca Alquran Dari Aplikasi," accessed November 27, 2021, https://www.cnnindonesia.com/teknologi/20210413150400-185-629333/muslim-pro-kini-orang-lebih-sukabaca-alquran-dari-aplikasi.

${ }^{5}$ Muhammad Yasir and Ade Jamaruddin, Studi Al-Qur'an, ed. Jani Arni (Pekanbaru: Asa Riau (CV. Asa Riau), 2016). 


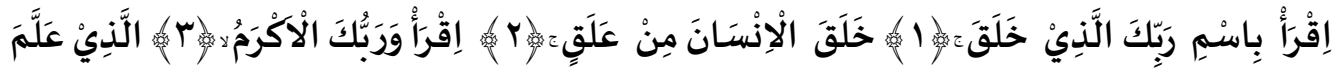

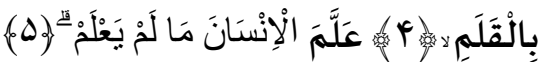

"Bacalah dengan (menyebut) nama Tuhanmu yang menciptakan, Dia telah menciptakan manusia dari segumpal darah. Bacalah, dan Tuhanmulah yang Mahamulia, yang mengajar (manusia) dengan perantara kalam. Dia mengajar kepada manusia apa yang tidak diketahuinya"

Dengan kehadiran aplikasi-aplikasi islami sebagai hasil dari perkembangan teknologi saat ini akan sangat berguna untuk menopang aktivitas ibadah membaca Al-Qur'an ummat islam khususnya generasi $\mathrm{Z}$ yang menguasai teknologi. Untuk itu, penelitian ini akan menyelidiki seberapa efektif aplikasi islami dalam meningkatkan kemampuan muslim atau muslimah Gen Z dalam membaca Al-Kitab yang tidak ada keraguannya ini. Di dalam kajian ini juga akan diberikan informasi mengenai kepemilikan aplikasi islami dan intensitas penggunaannya pada generasi Z.

\section{B. Metode Penelitian/Metode Kajian}

Penelitian ini menggunakan pendekatan kuantitatif yang bertujuan untuk menguji teori, membangun fakta, menunjukkan hubungan antar variable, memeberikan deskripsi statistik, menaksir dan meramalkan hasilnya ${ }^{6}$. Populasi penelitian yang sangat luas mengakibatkan penelitian ini tidak dapat mencapai jauh kedalam sebagaimana penelitian kasus, oleh karena itu digunakanlah format deskriptif survei yang memungkinkan peneliti dapat menggeneralisasi suatu gejala sosial dengan populasi yang lebih besar ${ }^{7}$.

Penelitian dilakukan dengan memanfaatkan google forms sebagai metode penelitian survei online. Google forms memberikan kemudahan dalam mengelola data yang diterima dari responden sehingga akses informasi yang dibutuhkan oleh peneliti dari responden menjadi lebih cepat dan secara otomatis tersimpan ${ }^{8}$. Pada link google forms yang disebarkan telah berisi pertanyaan-pertanyaan mengenai penggunaan aplikasi islami, selanjutnya responden yang memiliki link tersebut dapat mengaksesnya dan memberikan jawaban atas pertanyaan tersebut.

\footnotetext{
${ }^{6}$ Jonathan Sarwono, Metode Penelitian Kuantitatif Dan Kualitatif, 1st ed. (Yogyakarta: Graha Ilmu, 2006).

${ }^{7}$ Abdullah Ma'ruf, Metodologi Penelitian Kuantitatif, 1st ed. (Sleman: Aswaja Pressindo).

8 "Metode Penelitian Survei Online Dengan Google Forms - Google Books," accessed November 27, 2021, https://www.google.co.id/books/edition/Metode_Penelitian_Survei_Online_dengan_G/u7ChDwAAQBAJ? $\mathrm{hl}=\mathrm{id} \& \mathrm{gbpv}=1 \&$ printsec $=$ frontcover .
} 
Responden dari riset ini diambil secara acak dengan waktu yang acak juga namun tetap pada batasan subjek generasi Z yang lahir antara tahun 1997 sampai dengan 2012 . Beberapa aplikasi islami seperti Al Quran, Al Quran Indonesia, Muslim Pro, dan aplikasiaplikasi serupa yang digunakan oleh responden, menjadi objek penelitian dengan mengacu kepada fitur membaca Al-Qur'an yang ada pada aplikasi tersebut.

\section{Hasil dan Pembahasan}

\section{Sajian Data}

Data yang didapat melalui responden yang telah mengisi survei online dengan platform google forms disajikan pada bagian ini. Data penelitian ini disajikan berdasarkan 85 responden generasi $\mathrm{Z}$ yang tersebar di berbagai daerah dan latar belakang yang beragam.

\section{a. Data Kepemilikan Aplikasi islami}

Data kepemilikan aplikasi islami didapat dari 85 responden yang berpartisipasi dalam survei online yang dilakukan oleh peneliti. Dari 85 responden yang memberikan jawabannya didapatkan data sebagai berikut.

Tabel 1. Data Kepemilikan Aplikas Islami

\begin{tabular}{|c|c|c|}
\hline No & Kepemilikan Aplikasi Islami & Jumlah \\
\hline 1 & Memiliki & 72 \\
\hline 2 & Tidak Memiliki & 13 \\
\hline
\end{tabular}

Sumber: Hasil Survei Responden

\section{b. Data Aplikasi Islami yang Digunakan oleh Generasi Z}

Data aplikasi islami yang digunakan oleh generasi $\mathrm{Z}$ diambil dari nama-nama aplikasi islami yang digunakan oleh 72 responden generasi $\mathrm{Z}$ pengguna aplikasi islami. Pada data ini responden bisa saja memiliki lebih dari satu aplikasi islami yang terpasang pada perangkatnya. Selanjutnya, aplikasi-aplikasi yang digunakan oleh responden dikategorikan untuk mengetahui apakah aplikasi tersebut menghadirkan fitur untuk membaca Al-Qur'an di dalamnya. 
Tabel 2. Data Nama Aplikas yang Digunakan oleh Generasi Z

\begin{tabular}{|c|c|c|c|}
\hline No & Nama Aplikasi & $\begin{array}{c}\text { Jumlah } \\
\text { Responden } \\
\text { Pengguna }\end{array}$ & $\begin{array}{c}\text { Memiliki Fitur } \\
\text { Membaca Al-Qur’an }\end{array}$ \\
\hline 1. & $\begin{array}{c}\text { Al Quran } 30 \text { Jus } \\
\text { Offline }\end{array}$ & 2 & Ya \\
\hline 2. & Al Quran & 7 & $\mathrm{Ya}$ \\
\hline 3. & $\begin{array}{c}\text { Al Quran Bahasa } \\
\text { Indonesia }\end{array}$ & 1 & Ya \\
\hline 4. & Al Quran Indonesia & 32 & $\mathrm{Ya}$ \\
\hline 5. & Al Quran Tajwid & 1 & Ya \\
\hline 6. & Al Quran Oflfine & 1 & Ya \\
\hline 7. & Al Quran MP3 & 1 & Ya \\
\hline 8. & BANTERApps & 1 & Ya \\
\hline 9. & BSI Mobile & 1 & Ya \\
\hline 10. & Counter tasbih digital & 1 & Tidak \\
\hline 11. & Golden Qur'an & 1 & Ya \\
\hline 12. & Lembaran Al Quran & 1 & $\mathrm{Ya}$ \\
\hline 13. & $\begin{array}{l}\text { Maulid Diba' } \\
\text { Lengkap }\end{array}$ & 1 & Tidak \\
\hline 14. & Murottal Quran & 1 & Ya \\
\hline 15. & Muslim pro & 19 & Ya \\
\hline 16. & $\begin{array}{l}\text { My Quran Al-Qur'an } \\
\text { dan Terjemahannya }\end{array}$ & 3 & Ya \\
\hline 17. & Qibla Direction & 1 & Ya \\
\hline 18. & Salaam & 1 & $\mathrm{Ya}$ \\
\hline 19. & Simple quran & 1 & Ya \\
\hline 20. & Tafsir Ibnu Katsir & 1 & Ya \\
\hline 21. & Umma & 2 & $\mathrm{Ya}$ \\
\hline 22. & VMuslim & 1 & $\mathrm{Ya}$ \\
\hline
\end{tabular}

Sumber: Hasil Survei Responden 
c. Data Fitur atau Fasilitas pada Aplikasi Islami yang Digunakan Generasi Z

Data fitur atau fasilitas pada aplikasi islami yang digunakan generasi $\mathrm{Z}$ diambil berdasarkan penggunaan 72 responden generasi $\mathrm{Z}$ pengguna aplikasi islami. Pada data ini, satu aplikasi bisa memiliki fitur atau fasilitas lebih dari satu dan setiap responden bisa saja memiliki lebih dari satu aplikasi pada perangkatnya, maka dari itu responden dapat memberikan jawaban lebih dari satu fitur. Berikut adalah sajian data fitur atau fasilitas pada aplikasi islami yang digunakan oleh generasi Z.

Tabel 3. Data Fitur atau Fasilitas pada Aplikasi Islami yang Digunakan Generasi Z

\begin{tabular}{|c|c|c|}
\hline No & Fitur & $\begin{array}{c}\text { Jumlah Reponden } \\
\text { Pengguna }\end{array}$ \\
\hline 1 & Baca Al-Qur'an & 67 \\
\hline 2 & Jadwal/Reminder Sholat & 39 \\
\hline 3 & Murattal Al-Qur'an & 29 \\
\hline 4 & Kalender Hijriah & 18 \\
\hline 5 & Penunjuk Arah Kiblat & 21 \\
\hline 6 & Tajwid Al-Qur'an & 2 \\
\hline 7 & Bcaan Shalawat Maulid & 1 \\
\hline 8 & Diba & 2 \\
\hline 9 & Dzikir & \\
\hline
\end{tabular}

Sumber: Hasil Survei Responden

\section{d. Data Intensitas Digunkannya Fitur Baca Al-Qur'an pada Aplikasi Islami}

Data intensitas digunakannya fitur baca Al-Qur'an pada aplikasi ilami diambil dari 70 responden yang memiliki aplikasi islami dengan fitur untuk membaca Al-Qur'an di dalamnya. Dari 70 responden tersebut diperoleh intensitas sebagai berikut. 
Tabel 4. Data Intensitas Digunkannya Fitur

Baca Al-Qur'an pada Aplikasi Islami

\begin{tabular}{|c|c|c|}
\hline No & Intensitas & $\begin{array}{c}\text { Jumlah } \\
\text { Responden }\end{array}$ \\
\hline 1 & Setiap hari & 10 \\
\hline 2 & Sering namun tidak setiap hari & 31 \\
\hline 3 & Seminggu sekali & 3 \\
\hline 4 & Jarang & 18 \\
\hline 5 & Sangat Jarang & 6 \\
\hline 6 & Tidak pernah & 2 \\
\hline
\end{tabular}

Sumber: Hasil Survei Responden

e. Data Pendapat Responden Mengenai Efektivitas Aplikasi Islami Terhadap Kemampuan Membaca Al-Qur'an

Data pandangan responden mengenai efektivitas aplikasi islami terhadap kemampuan membaca Al-Qur'an diambil melalui 70 responden yang pemilik aplikasi islami dengan fitur membaca Al-Qur'an didalamnya. Dari 70 responden tersebut didapatkan data sebagai berikut.

Tabel 5. Data Pendapat Responden Mengenai Efektivitas Aplikasi Islami Terhadap Kemampuan Membaca Al-Qur'an

\begin{tabular}{|c|c|c|}
\hline No & Pendapat & $\begin{array}{c}\text { Jumlah } \\
\text { Reponden }\end{array}$ \\
\hline 1 & $\begin{array}{c}\text { Meningkatkan kemampuan membaca Al- } \\
\text { Qur'an }\end{array}$ & 42 \\
\hline 2 & $\begin{array}{c}\text { Sedikit meningkatkan kemampuan } \\
\text { membaca Al-Qur'an }\end{array}$ & 7 \\
\hline 3 & Tidak meningkatkan kemampuan \\
membaca Al-Qur'an & 21 \\
\hline
\end{tabular}

Sumber: Hasil Survei Responden 


\section{Analisis dan Pembahasan}

Pada analisis dan pembahasan, data-data dari jawaban responden dianalisis dan dibahas menjadi tiga aspek yaitu kepemilikan aplikasi islami pada generasi $\mathrm{Z}$, intensisitas digunakannya fitur untuk membaca Al-Qur'an pada aplikasi islami, dan pendapat responden mengenai efektivitas aplikasi islami terhadap kemampuan membaca Al-Qur'an.

\section{a. Kepemilikan Aplikasi Islami pada Generasi Z}

\section{Gambar 1.Kepemilikan Aplikasi Islami pada Generasi Z}

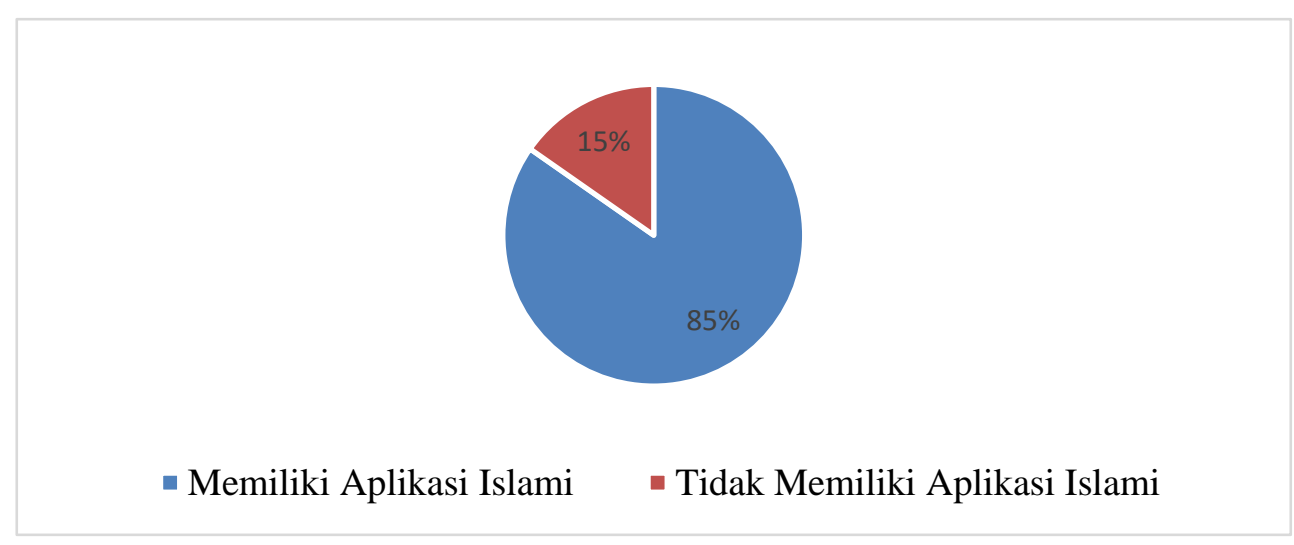

Gambar 1 menjelaskan bahwa sebanyak 72 responden terkategori memiliki aplikasi islami yang terpasang pada perangkat smartphone miliknya. Penelitian yang dilakukan menghasilkan data bahwa fitur membaca Al-Qur'an merupakan fitur yang tersering dimanfaatkan oleh responden (93\%). Selain fitur tersebut, 53\% responden juga memanfaatkan fitur jadwal atau reminder sholat pada aplikasi yang mereka gunakan. Selanjutnya diikuti oleh fitur murattal al-Qur'an, penunjuk arah kiblat, dan kalender hijriah yang masing-masing digunakan oleh 40\%, 29\%, dan 25\% responden pemilik aplikasi islami.

Dari 72 responden yang menggunakan aplikasi islami, didapatkan 22 jenis aplikasi yang digunakannya. Sebanyak 20 aplikasi diketahui memiliki fitur untuk membaca AlQur'an di dalamnya. Dua aplikasi aplikasi yang paling banyak digunakan oleh responden antara lain Al Quran Indonesia yang digunakan oleh 32 responden dan aplikasi Muslim Pro yang digunkanan oleh 19 responden. Aplikasi Al Quran Indonesia adalah aplikasi Al-Qur'an digital dengan terjemahan Bahasa Indonesia dan audio mp3 murattal full dengan 8 pilihan qori, 114 surah atau 30 jus tanpa pembatasan yang dapat dibaca secara offline dan tampilan yang user friendly ${ }^{9}$, sedangkan aplikasi Muslim Pro diklaim sebagai aplikasi muslim paling

\footnotetext{
9 “Al Quran Indonesia - Aplikasi Di Google Play,” accessed November 27, 2021, https://play.google.com/store/apps/details?id=com.andi.alquran.id\&hl=in\&gl=US.
} 
popular dan 50 juta pengguna di Play Store telah mengunduhnya. Aplikasi ini dikenal sebagai aplikasi pengingat waktu sholat dan adzan terakurat, Muslim Pro juga memiliki fitur Al-Qur'an bertulisan Arab lengkap dengan fonetik, terjemahan, serta resitasi audio. Selain itu, dilengkapi juga dengan fitur penunjuk arah Kiblat, kalender Hijriyah, serta peta untuk menemukan lokasi rumah makan halal, Masjid, dan lain-lain ${ }^{10}$. Berdasarkan data yang diterima, beberapa responden tercatat menggunakan lebih dari satu aplikasi pada perangkatnya. Sementara itu 2 responden menggunakan aplikasi islami yang tidak menghadirkan fitur baca Al-Qur'an. Dua aplikasi tersebut adalah aplikasi yang digunakan untuk menghitung tasbih dan aplikasi maulid diba'.

b. Intensisitas Digunakannya Fitur Untuk Membaca Al-Qur'an pada Aplikasi Islami

Gambar 2. Intensisitas Digunakannya Fitur Untuk Membaca Al-Qur'an

\section{pada Aplikasi Islami}

$\begin{aligned} & \\ & \\ & =\text { Setiap hari } \\ & =\text { Seminggu sekali } \\ & =\text { Sangat Jarang } \\ & =\text { Jidak pernah namun tidak setiap hari }\end{aligned}$

Gambar 2 menunjukkan bahwa mayoritas responden Gen $\mathrm{Z}$ yang menggunakan aplikasi Islami masih belum menggunakan fitur membaca Al-Qur'an pada aplikasi islami untuk setiap harinya. Dari total 70 responden pengguna aplikasi islami dengan fitur membaca Al-Qur'an didalamnya, sebanyak 10 responden saja yang rutin menggunakan fitur membaca Al-Qur'an pada aplikasi islaminya secara harian. Sebanyak 31 responden mengatakan bahwa mereka cukup sering menggunakan aplikasi islami untuk membaca Al-Qur'an tetapi intensitasnya tidak rutin setiap hari. Sebagian besar responden berpendapat bahwa aplikasi islami

\footnotetext{
10 "Muslim Pro Adzan Sholat Kiblat - Aplikasi Di Google Play," accessed November 27, 2021,
} https://play.google.com/store/apps/details?id=com.bitsmedia.android.muslimpro\&hl=in\&gl=US. 
memberikan fleksibilitas untuk membaca Al-Qur'an tanpa terbatas tempat maupun waktu, sehingga aplikasi islami ini memberikan dampak dalam meningkatnya intensitas membaca Al-Qur'an. Sementara itu, 18 responden mengatakan bahwa mereka jarang menggunakan aplikasi islami untuk membaca Al-Qur'an, bahkan 6 responden mengatakan bahwa mereka sangat jarang menggunakan aplikasi islami untuk membaca Al-Qur'an. Jumlah ini ditambah lagi oleh dua orang responden yang menyatakan bahwa dirinya belum pernah menggunakan aplikasi islami untuk membaca Al-Qur'an. Mereka yang dikategorikan jarang bahkan tidak pernah menggunakan fitur baca Al-Qu'an pada aplikasi islami mayoritas beralasan karena mereka lebih nyaman untuk membaca melalui mushaf Al-Qur'an atau dalam arti lain mereka lebih nyaman membaca Al-Qur'an melalui lembaran-lembarannya. Beberapa dari mereka juga beralasan hanya menggunakan aplikasi islami untuk membaca Al-Qur'an di kondisi tertentu saja semisal sedang tidak ada mushaf dan sedang berhalangan. Seorang responden menilai bahwa membaca Al-Qur'an melalui mushafnya memberikannya rasa khusu' yang lebih dibanding melalui aplikasi, hal ini karena dirinya kerap merasa terganggu notifikasi yang masuk ketika membaca Al-Qur'an melalui perangkat.Terlepas dari seberapa sering responden membaca AlQur'an, responden berpendapat bahwa aplikasi islami dengan fitur untuk membaca Al-Qur'an-nya menyajikan banyak kemudahan bagi penggunanya. Kemudahan tersebut diantaranya kehadiran tajwid dan murattal dinilai memberikan kemudahan untuk malafazkan ayat-ayat Al-Qur'an dengan sempurna. Disamping memberikan fleksibilitas, responden mengatakan bahwa aplikasi islami lebih efisien dan lebih praktis. Salah satu responden mengatakan bahwa sebagai generasi Z, adanya aplikasi islami membuat dirinya tidak merasa gengsi ketika ingin membaca Al-Qur'an. Seorang responden lainnya lagi menyatakan bahwa telah menjadi kebiasaannya membaca Al-Qur'an melalui aplikasi islami. 


\section{c. Pendapat Responden Mengenai Efektivitas Aplikasi Islami Terhadap Kemampuan Membaca Al-Qur'an}

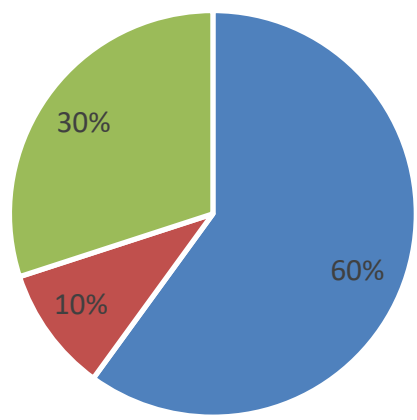

- Meningkatkan kemampuan membaca Al-Qur'an

- Sedikit meningkatkan kemampuan membaca Al-Qur'an

- Tidak meningkatkan kemampuan membaca Al-Qur'an

Gambar 3. Pendapat Responden Mengenai Efektivitas Aplikasi Islami Terhadap

\section{Kemampuan Membaca Al-Qur'an}

Dalam sajian sebelumnya, diketahui sebanyak 58\% responden menggunakan aplikasi islami dengan intensitas lebih dari satu kali dalam seminggu untuk membaca Al-Qur'an. Intensitas ini dapat dikategorikan cukup tinggi sehingga perlu untuk diketahui apakah aplikasi islami ini memberikan dampak pada kemampaun membaca Al-Qur'an penggunanya. Berdasarkan pendapat para responden, $60 \%$ responden mengatakan bahwa aplikasi islami yang mereka gunakan memberikan peningkatan pada keterampilan membaca Al-Qur'an dirinya. Umumnya responden menyatakan bahwa fitur membaca Al-Qur'an pada aplikasi islami telah menambah kualitas membaca Al-Qur'an-nya karena aplikasi islami menghadirkan fasiltas-fasilitas pendukung seperti tajwid dan murattal yang dapat memperjelas penggunanya untuk melafazkan ayat Al-Qur'an dengan lebih sedikit kesalahan. Kemudian fasilitas-fasilitas tersebut dibungkus dalam sebuah aplikasi yang membuatnya lebih praktis dan fleksibel sehingga penggunanya dapat membaca kapanpun dan dimanapun. Fleksibilitas inilah yang memberikan dorongan kepada penggunanya supaya membaca AlQur'an pada aplikasi islaminya menjadi lebih sering lagi.

Berbeda dengan mayoritas responden yang menilai aplikasi islami telah memberikan dampak yang menguntungkan terhadap keterampilan membaca Al-Qur'an-nya, 10\% responden menyatakan hanya sedikit peningkatan kemampuan membaca Al-Qur'an jika dirinya menggunakan aplikasi islami. Dari sudut pandang lain sebanyak 30\% responden lainnya menilai bahwa aplikasi islami tidak sama sekali meningkatkan kemampuannya 
membaca Al-Qur'an. Seorang responden mengatakan bahwa akan lebih efektif jika ada seseorang yang menyimak maupun guru yang secara langsung mengajarkannya supaya bisa menambah kemampuan membaca Al-Qur'an dirinya. Selain dari itu, responden lain berpendapat bahwa kenyamanan dan fokus ketika membaca mushaf Al-Qur'an tidak bisa didapatkan dari membaca dengan aplikasi melalui perangkat yang digenggam.

\section{Penutup}

Kepemilikan aplikasi islami pada muslim dan muslimah generasi $\mathrm{Z}$ tergolong tinggi yaitu 85\%. Angka ini menunjukkan bahwa sebagian besar muslim dan Muslimah generasi Z telah menggunakan aplikasi islami pada perangkat smartphone miliknya. Diantara fitur dan fasilitas yang dihadirkan dalam aplikasi tersebut, fitur membaca Al-Qur'an merupakan fitur terbanyak digunakan oleh generasi Z, sebanyak 93\% generasi Z menggunakan fitur membaca Al-Qur'an pada aplikasi islaminya. Meskipun generasi Z cenderung tidak menggunakan aplikasi islami untuk membaca Al-Qur'an setiap hari, sebanyak 58\% Gen Z membaca Al-Qur'an melalui aplikasi islami pada intensitas lebih dari satu kali dalam seminggu.

Mayoritas muslim dan muslimah generasi $\mathrm{Z}$ berpendapat bahwa aplikasi islami mereka gunakan memberikan peningkatan terhadap kemampuan membaca Al-Qur'an dirinya. Pendapat tersebut didasari oleh fasiltas pendukung dalam aplikasi islami yang telah membantu penggunanya untuk meminimalisir kesalahan dalam melafazkan ayat-ayat AlQur'an, terlebih sifat praktis dan fleksibilitasnya membuat penggunanya bisa menambah intensitas membaca Al-Qur'an tanpa terbatasnya tempat maupun waktu. Sebanyak 60\% pendapat generasi $\mathrm{Z}$ inilah yang menjadikan aplikasi islami dirasa cukup efektif bagi generasi Z untuk meningkatkan kemampuan membaca Al-Qur'an-nya. Meskipun dalam penelitian ini aplikasi islami dinyatakan cukup efektif, diharapkan agar tidak menjadikan hasil karya ini sebagai pedoman mutlak untuk menggambarkan objek yang diteliti karena masih banyak kekurangan dalam penelitian ini dan tidak menutup kemungkinan terdapat fakor eksternal yang dapat mempengaruhinya. 


\section{E. Daftar Pustaka}

Badan Pusat Statistik. Hasil Sensus Penduduk 2020 Berita Resmi Statistik No. 7/01/Th. XXIV, 21 Januari 2021, n.d.

Effendi, M. R. (2021). Teologi Islam; Potret Sejarah dan Perkembangan Mazhab KAlam. Literasi Nusantara.

Effendi, M. R., Nurparatiwi, S., Narulita, S., Tsaqila, D. F., \& Nurhidayat, M. (2021). Penguatan Softskill Guru Dalam Upaya Peningkatan Etos Belajar Peserta Didik Pada Masa PAndemi Covid-19. Sivitas: Jurnal Pengabdian dan Pemberdayaan Masyarakat, 1(2), 41-51.

Ma'ruf, Abdullah. Metodologi Penelitian Kuantitatif. 1st ed. Sleman: Aswaja Pressindo.

Narulita, S., Aulia, R. N., Barnansyah, M. R., Aminah, A., \& as Suminar, M. Z. (2019). Pengembangan Kompetensi Guru dalam Pembelajaran PAI bagi Generasi Z. Publikasi Pendidikan, 9(3), 217-221.

Nurpratiwi, S., Effendi, M. R., \& Amaliyah, A. (2021). Improving Religious Literacy Through Islamic Religious Education Course Based On The Flipped Classroom. Istawa: Jurnal Pendidikan Islam, 6(1), 16-29.

Nurpratiwi, S., Ridwan Effendi, . M., \& M Barnansyah, R. (2021). Self-Reflection of Prospective Teacher Students On Tpack Ability Through Case-Based Learning Model. Muttaqien Publishing, 1(1), 21-29.

Halim, A., Anggraeni, D., \& Fadhil, A. (2021). Pembelajaran Al-Quran Berbasis Edutainment. Jurnal Studi Al-Qur'an , 17(1), 75 - 92.

Hidayat, A. A., Effendi, M. R., \& Hakam, A. (2021). Religion and Tradition: Overview of Culture and Islamic Acculturation in The Ciptagelar Society. Muttaqien Publishing, 1(1), 223-232.

Rastati, Ranny. "MEDIA LITERASI BAGI DIGITAL NATIVES: PERSPEKTIF GENERASI Z DI JAKARTA.”Jurnal Kwangsan 6, no. 1 (June 29, 2018): 60.

Sarwono, Jonathan. Metode Penelitian Kuantitatif Dan Kualitatif. 1st ed. Yogyakarta: Graha Ilmu, 2006.

Siti Julaeha, E., Ridwan Effendi, M., \& Karnafi. (2021). Everyone is Teacher Here Method and Its Effectiveness On Learning Outcomes of Akidah Akhlak. Muttaqien Publishing, 1(1), 91-104.

Yasir, Muhammad, and Ade Jamaruddin. Studi Al-Qur'an. Edited by Jani Arni. Pekanbaru: Asa Riau (CV. Asa Riau), 2016. 
“Al Quran Indonesia - Aplikasi Di Google Play.” Accessed November 27, 2021. https://play.google.com/store/apps/details?id=com.andi.alquran.id\&hl=in\&gl=US.

"KEPEMIMPINAN MASA KINI - Google Books.” Accessed November 27, 2021. https://www.google.co.id/books/edition/KEPEMIMPINAN_MASA_KINI/rosaEAAA QBAJ?hl=id\&gbpv=1\&printsec=frontcover.

"Metode Penelitian Survei Online Dengan Google Forms - Google Books." Accessed November 27 , 2021. https://www.google.co.id/books/edition/Metode_Penelitian_Survei_Online_dengan_G /u7ChDwAAQBAJ?hl=id\&gbpv=1\&printsec=frontcover.

"Muslim Pro: Kini Orang Lebih Suka Baca Alquran Dari Aplikasi." Accessed November 27, 2021. https://www.cnnindonesia.com/teknologi/20210413150400-185629333/muslim-pro-kini-orang-lebih-suka-baca-alquran-dari-aplikasi.

"Muslim Pro Adzan Sholat Kiblat - Aplikasi Di Google Play." Accessed November 27, 2021.

https://play.google.com/store/apps/details?id=com.bitsmedia.android.muslimpro\&hl=i $\mathrm{n} \& \mathrm{gl}=\mathrm{US}$. 